\title{
ポーラログラフィ法による春髅組織酸素 分圧の実験的測定
}

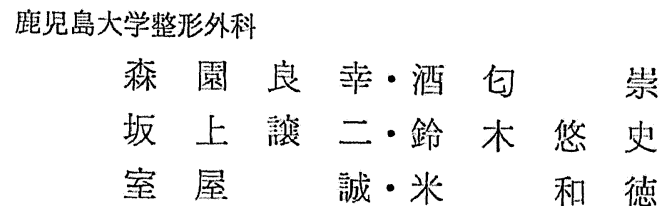

\section{Spinal cord tissue oxygen measured by polarographical tecnique in rabbits}

by

\author{
Y. Morizono, T. Sakou, J. Sakagami, Y. Suzuki, \\ M. Muroya and K. Yone. \\ Department of Orthopeadic Surgery, Faculty of Medicine, \\ Kagoshima University.
}

\begin{abstract}
Partial tissue oxygen pressure in the spinal cord was measured in the rabbits by polarographical method. The study was done in the thoracic cord after laminectomy of T6, T7 and T8 with a small size of needle electrodes being inserted. The average $\mathrm{PO}_{2}$ showed $11.9 \pm 0.9 \mathrm{mmHg}$ in the white matter and $26.7 \pm 3.3 \mathrm{mmHg}$ in the gray matter. The blood pressure was maintained within the normal range, $80-120 \mathrm{mmHg}$ during the determination. Then the blood pressure was made changed by venous administration of noraderenaline and trimetaphane. The $\mathrm{PO}_{2}$ showed to increase or decrease parallel in proportion to that of blood pressure. In addition, $\mathrm{PO}_{2}$ in the spinal cord showed a rapid increase when pure oxygen gas was inspired through intubation.
\end{abstract}

金属電極による 組織酸 素分圧の测定は, Montgomery 以来，多くの研究者により 報告されている が, 脊髅実質内組織 $\mathrm{PO}_{2}$ 亿関しての研究は少なく, 前田 (1965), Kelly (1970), Ducker (1971), らの あのがある．しかし量的測定についての報告は不明な 点が多く，また测定技術面における問題が多いようで ある、私達むポーラログラフィーを応用して，成熟家 兔の泰䯣実質内組織 $\mathrm{PO}_{2}$ を測定し，検討を加えたの で報告する.

$$
\text { 方法 }
$$

测定装置は，ュニークメディカル社製 POG-200 A を用いた．実験動物は成熟家愁 20 羽 (平均体重 $2 \mathrm{~kg}$ )

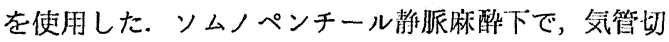
開にて気管内挿管し，レスピレーターにより調節呼吸 を行ない，動脈血 $\mathrm{PO}_{2}, \mathrm{PCO}_{2}, \mathrm{PH}$ 值を正常箱囲にコ

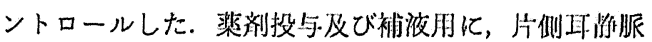
を確保，片例大腿政㖘には血压测定用カテーテルを㨂 入し，全身血压を速続的に测定した．休温モニターと して，淔腸温を記録した，家㣽は政物固定器（Suspension 式，自家製）に固定した. 测定前, 猃渡柾 は窒奖ガスで飽和された $37^{\circ} \mathrm{C}$ 生食内で 0 刻節をした 後, room air で飽和された $37^{\circ} \mathrm{C}$ 生企水で 150 $\mathrm{mmHg}$ 調節を行なった，乙机を 2 回行い，嵒差の少

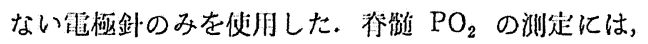
胸椎 $6,7,8$ 志椎弓切除後, 䫓微鏡下に硬榄, クモ榄

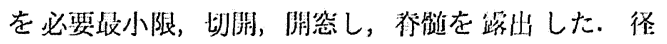

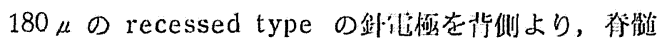
実所内に刺入した。灰白馆部 $\mathrm{PO}_{2}$ 测定には，中央部 で $2 \mathrm{~mm}$ の樑さ, 白欣部 $\mathrm{PO}_{2}$ 测定には, 僛方 $1 \mathrm{~mm}$ の刺入とした，不园伲極は，北侧皮下に埋没した．乙 のようにして测定した $\mathrm{PO}_{2}$ 值の, 景圧剂や降圧剂に 


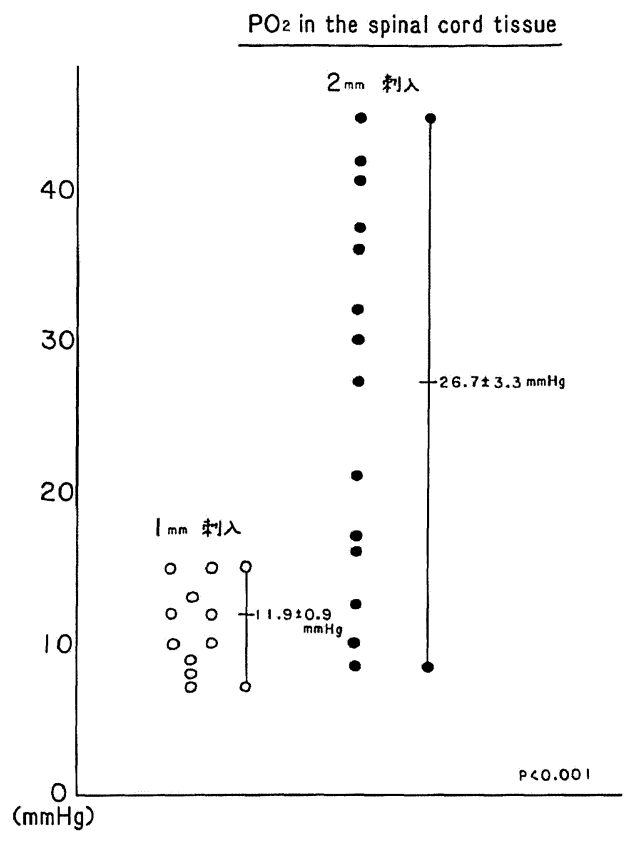

図 1

よる全身血圧の変動や，純酸素吸入による大動脈 $\mathrm{PO}_{2}$ 值の変動などの関連性についても観察を行った. また実験終了後, 测定部の脊䯣の組織学的検索を行っ た.

\section{結果}

白質と思われる $1 \mathrm{~mm}$ 刺入群での $\mathrm{PO}_{2}$ 值は計 11 回の刺入で, $7 \mathrm{mmHg}$ より $17 \mathrm{mmHg}$ に及び, 平均 $11.9 \pm 0.9 \mathrm{mmHg}$ である. 灰白質之思的れる $2 \mathrm{~mm}$ 刺入群の $\mathrm{PO}_{2}$ 佔は, 計 14 回の刺入で, $8.75 \mathrm{mmHg}$ より $45 \mathrm{mmHg}$ に及び, 平均 $26.7 \pm 3.3 \mathrm{mmHg}$ であ る(図 1) $(\mathrm{P}<0.001)$. 次に $0.002 \%$ Noradrenaline 投与の血圧上景に上る, 脊能 $\mathrm{PO}_{2}$ 之筋肉 $\mathrm{PO}_{2}$ の変化を検討した. 脊哈 $\mathrm{PO}_{2}$ は，全身血圧の上昇に ほぼ比例して上帠し，血圧下降に比例して下降を示 し，血压の正常化にほぼ比例して正常に復した. 一方 筋肉 $\mathrm{PO}_{2}$ は Noradrenaline 投与. 3 分後に, 最高値 を示し, 以後しだいに下降, 投与後約 20 分で最低值 となり,その後しだいに上昇, 投与後 50 分で, 投与 前に復した（図 2). $0.002 \%$ Trimetaphane 投与. の血珐下降による影響では，脊䯣 $\mathrm{PO}_{2}$ は，血圧の急 激な下降に比例して，下降し，血压の正常化にほぼ比 例して，正常に復した，一方筋肉 $\mathrm{PO}_{2}$ は，血圧に比

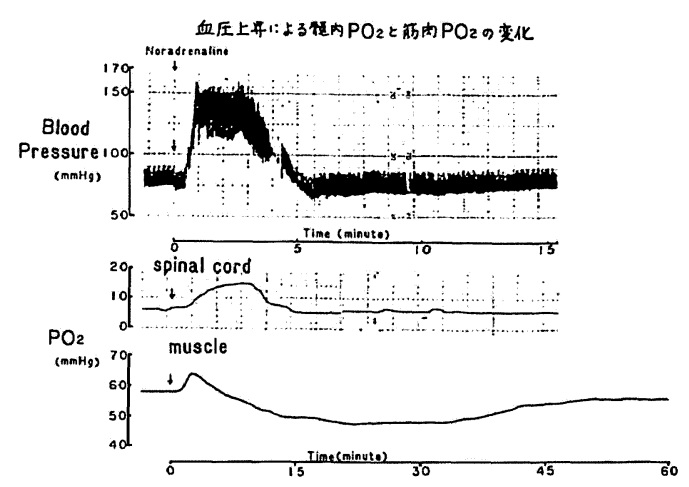

図2

血压下降による髄内 $\mathrm{PO}_{2}$ と筋肉 $\mathrm{PO}_{2}$ の变化

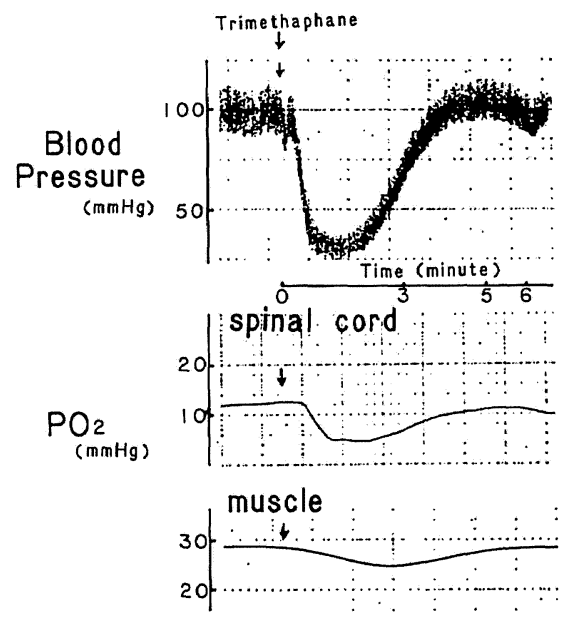

図 3

例するが，緩徐であった(図 3 ). 血圧上㫤，下降両群 之も実験中, 動脈血 $\mathrm{PO}_{2}, \mathrm{PCO}_{2}$ は正常簌囲であった. 次化純酸素吸入に上る組織 $\mathrm{PO}_{2}$ は, 春䯣, 筋肉組織 とむ，吸入後，約 1 分で 組織酸糸分圧の上昇を認め た. 春融 $\mathrm{PO}_{2}$ は純酸素吸入解除之共に, 急速に下降 を示したが，筇肉 $\mathrm{PO}_{2}$ は，緩徐であった. 乙の操作 の間，全身血液及び血中 $\mathrm{PCO}_{2}$ はほとんど一定であ

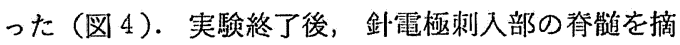
出し, 組織学的検索を行った，従来の電極針を刺入後 の脊䯣組織の H-E 染色では, 刺入部の先端に大きな 出血鉴を認めたが，現在使用中の電極針では，刺入部 の微少な出血巣を認めるのみであった，又実験終了 後，麻渖状態を観察した家鬼では，琴在の使用電極剑 においては，1例も㑣疩を認めなかった。 


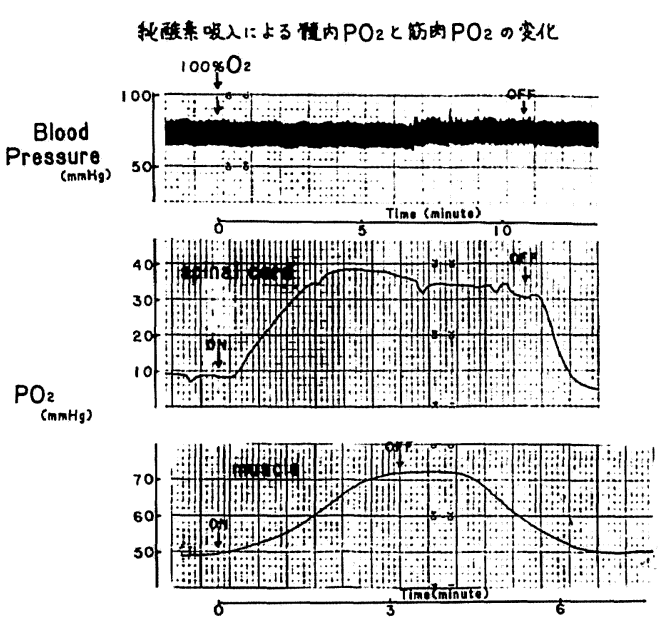

図 5

考

察

Polarography を応用し，正常家鬼脊髉組織 酸 絜 分圧を連続的に, 定量测定した. この Polarography は容存する酸素量に比例して，脱分極電流がおこる原 因に基づいている. 酸素電極の電流を左右する因子と して, 1) 電極の動摇, 2) 酸素拡散係数の 変化, 3) 体循環における酸素濃度，4）局所血流，5）局 所組織の酸素消費，6）出血による赤血球の存在など が考えられている. 我々は全身晽醉下，レスピレータ 一による調節呼吸，体温の一定化，電極針の 固定, suspension 式動物固定器の使用により，1）～ 5 ) の因子を一定の条件に保った．また6）の因子を最小 限におさえる為, 微少電極の作製に努力した. これは また泰髄組織内酸素分圧の测定においては，出血によ る影響のほかに，麻疩を生じないととが要求されるか らである．また針自体の安定性因子としては，ノイズ やドリフト，動摇影響，污染に対する抵抗性，感度の 酸素浱度に対する直線性, 応答の早さ, 残余電流の大 小等が挙げられるが，膜付電極の使用や，実験前の綿 密な針の check 等により, より安定した data が得 られるすのと考えている.

現在まで正常脊䯣契質内組織酸絭分王の紿刘値测定
は, Kelly, Ducker らのみにより報告されており， それぞれの测定值は Kelly: 15〜30 $\mathrm{mmHg}$ (大)， Ducker: $39 \pm 3$ と $36 \pm 2 \mathrm{mmHg}$ (犬) である. しか

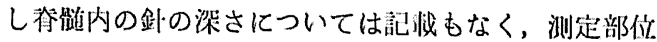

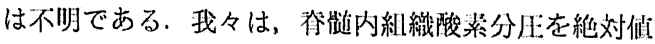

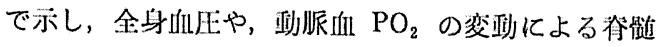

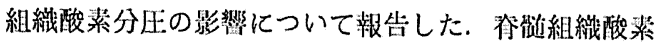
分生は，全身血王の上显，下降に対して，auto-regu-

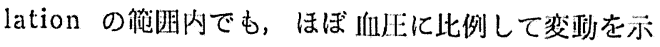
した.

\section{文献}

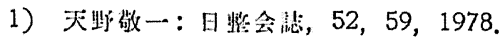

2) Ducker, T. B. et al: Surg. Neurol. 10, 60, 1978.

3) Ducker, T. B. et al.: Surg. Forum. 22, 413, 1971.

4) Hales, J. R. S. et al.: J. Neurosurg. 54, 620, 1981.

5) Kelly, D. L. et al.: J. Neurosurg. 36, $425,1972$.

6) Kelly, D. L. et al.: J. Neurosurg. 33, $554,1970$.

7）前四信㼁：奈良医学篗誌，16，429，1965.

8) Robert, M. et al.: J. Neurosurg. 37, 706, 1972.

9）八木舎西ほか：岩手医学准誌，15，193，1963.

質 問総合金提センター 位々木扼雄

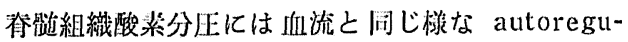
lation system はありますか.

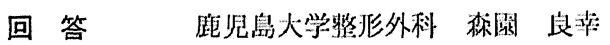

脊䯣組織 $\mathrm{PO}_{2}$ は，血圧上䒜，下降にほぼ平行して 変動を示した. 又純酸素吸入では，1 分後に $\mathrm{PO}_{2}$ 值 の上昇を示し，プラトーを形成，吸入中止を其に下降 を示した.

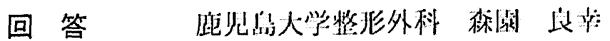

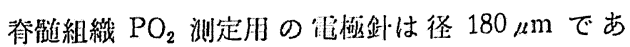
り，血流測定用泊極針は径 $100 \mu \mathrm{m}$ である. 